https://helda.helsinki.fi

Tenure structure and perceived social disorder in post-WWII suburban housing estates : A multi-level study with a representative sample of estates

Kemppainen, Teemu Tapio

2018-08-01

Kemppainen , T T , Kauppinen, T M , Stjernberg , M A \& Sund , R T 2018 , ' Tenure structure and perceived social disorder in post-WWII suburban housing estates : A multi-level study with a representative sample of estates ' , Acta Sociologica, vol. 61, no. 3 , pp. 246-262 . https://doi.org/10.1177/0001699317699052

http://hdl.handle.net/10138/308538

https://doi.org/10.1177/0001699317699052

acceptedVersion

Downloaded from Helda, University of Helsinki institutional repository.

This is an electronic reprint of the original article.

This reprint may differ from the original in pagination and typographic detail.

Please cite the original version. 


\title{
Tenure structure and perceived social disorder in post-WWII suburban housing estates: A multi-level study with a representative sample of estates
}

(Accepted for publication in Acta Sociologica)

Teemu Kemppainen, Department of Social Research, University of Helsinki, Finland Timo M Kauppinen, National Institute for Health and Welfare, Finland Mats Stjernberg, Department of Geosciences and Geography, University of Helsinki, Finland Reijo Sund, Department of Social Research, University of Helsinki, Finland

\begin{abstract}
Studies on post-WWII housing estates have largely focused on problematic neighbourhoods, and there is scarcity of literature on housing estates across their entire social scale. Moreover, there is insufficient evidence on the extent to which tenure structure differentiates estates from each other in terms of social disorder. Using a large cluster sample of Finnish estates representing a wide variety of estate neighbourhoods, we examined the implications of tenure structure in terms of social disadvantage and perceived social disorder. We also studied how social interaction and normative regulation mediate the impact of structural estate characteristics. We found that rental domination is associated with social disadvantage, which exposes residents to social disorder, in line with social disorganisation theory. Differences in normative regulation partly explain this association. In contrast, social interaction in the neighbourhood is not associated with the level of perceived social disorder. The theoretical and practical implications of the results are discussed.
\end{abstract}

\section{Keywords}

Housing estates, tenure mix, social disorganisation, social disorder, incivilities, neighbourhood 


\section{Introduction}

Spatial concentration of social disadvantage is a recurrent concern in modern societies and it has a central place in the literature on post-WWII housing estates as well. Estate neighbourhoods are often associated with various closely-related social and economic problems, including high unemployment, low income and education level, social stigmatisation, problems of social order, and insecurity (Murie et al., 2003; Dekker and van Kempen, 2005; Wassenberg, 2013). However, estates are diverse and not all of them are affected by these problems; some estates are in fact quite affluent neighbourhoods (Kemppainen \& Saarsalmi, 2015). One of the factors shaping the level of social disadvantage of an estate is tenure structure. The estates dominated by rental and, especially, social rental housing, tend to be more disadvantaged. Even though there is abundant literature on tenure mixing, there is a documented need for further high-quality large-scale evidence on the implications of mixed tenure policies (Sautkina et al., 2012). More specifically, the evidence on the association of tenure structure with the nature of local social life is scarce. The present study addresses this topic by asking to what extent tenure structure differentiates estates from each other in terms of social disorder.

Examining the variation of tenure structure and its implications within a single country is a promising analytical path. For example, in Finland post-WWII estates differ markedly from each other in terms of tenure structure. In some regions of the country, explicit policy measures have consistently regulated the share of social rental housing in the very construction of estates, thus impacting on the spatial patterns of social disadvantage. Focusing on post-WWII estates provides an added analytic advantage because the type of the built environment is relatively homogeneous, which diminishes confounding variation. Altogether, this kind of setting constitutes an analytically fruitful frame for examining the outcomes of mixed tenure policies.

In this study, we examine a group of 70 Finnish estates in order to elucidate whether tenure structure has implications regarding the residents' perceptions of social disorder. We use recent survey and register data on 70 Finnish post-WWII housing estates built in the 1960s and 1970s. The survey was collected for the purpose of this study in 2013. By studying the social mechanisms that link the structural neighbourhood properties to perceived disorder, we contribute not only to literature on housing estates, but also to more general sociological questions on norms, regulation and social order. Social disorder refers here to disturbances or incivilities one may encounter in the neighbourhood, such as public drunkenness, vandalism, threatening behaviour, and the like (see Covington and Taylor, 1991; Sampson \& Raudenbush, 1999). It has been found to be a central factor regarding fear of crime and feelings of insecurity (Brunton-Smith and Sturgis, 2011; Kemppainen et al., 2014) as well as segregation dynamics (Andersson and Bråmå, 2004; Varady and Schulman, 2007; Skifter Andersen, 2008). Furthermore, stressful neighbourhood conditions may expose residents to health problems (Kim, 2008; Steptoe and Feldman, 2001).

In what follows, we introduce the background and prior findings in order to conceptualise and position our study. After this, we present and discuss our findings, which show that the tenure structure of the estate is a key factor that shapes the perceptions of local social disorder. 


\section{Background}

Social disorder

Contemporary theoretical discussion on social disorder has touched upon measurement issues and context-dependence. First, the measurement discussion is largely about who is seen as the best observer of these phenomena. The defenders of survey measurement consider residents to be the experts on the social life in their neighbourhood (e.g. Ross and Mirowsky, 1999; Hipp, 2007). For example, residents have a longer observation frame than outsider-observers, which is beneficial when assessing the prevalence of social disorder. Moreover, we can argue that if we want to understand residents' living conditions and decisions, their subjective perceptions are of key importance. However, this approach may be complicated by individual psychological dispositions. Those more prone to, say, feelings of insecurity may also report higher levels of neighbourhood disorder due to their own perception schemes. Systematic social observation, referring to rule-guided, ideally replicable measurement performed by trained observers, has been proposed as an alternative approach (Sampson \& Raudenbush, 1999). In this study section, we propose a different solution to this problem, based on splitting the data to obtain results purged from this kind of confounding.

Second, it has been argued that the interpretation of the signs of disorder as a problem depends on the social context in which the interpretation is made (Sampson, 2009). However, it is one thing to report how much one has seen a given phenomenon in the neighbourhood and another to judge its seriousness as a problem (e.g. Friedrichs and Blasius, 2003). To what extent the context-dependence, framed explicitly in terms of problem judgment, applies to a more descriptive perception is an open question theoretically and empirically. Here, we operationalise perceived social disorder in a descriptive manner, as seen in the methods section.

\section{Suburban housing estates}

Suburban housing estates ('lähiö' in Finnish) are products of post-WWII planning, characterised by a distinct type of built environment, mainly consisting of prefabricated multi-storey apartment blocks, typically located in peripheral surroundings on the urban fringes. Most suburban housing estates in Finland were built during the 1960s and 1970s, and the rationale was to provide housing for the rapidly growing urban population (Hankonen, 1994). Although these neighbourhoods have suffered from weak reputation for several decades, it is only since the 1990s they have become associated with deeper structural problems, related to structural changes in the economy, increasing levels of social inequality and socio-spatial differentiation. As a consequence, their socio-economic development has generally been unfavourable during the last decades, seen for instance in the high rates of unemployment and comparatively low levels of income and education in many Finnish housing estates (Stjernberg, 2015). In this study, we focus on the estates built in the 1960s and 1970s because of their central place in the public debate on segregation and because they constitute a distinct type of built environment that is clearly different from the preceding and following suburban developments. The estates built in these two decades show a wide variation in many respects, including demographic and socio-economic measures and also tenure structure. Contrary to the owner-occupied low-rise neighbourhoods, the most typical tenure structure of these estates is a mixed one (Kemppainen \& Saarsalmi, 2015). 


\section{Social integration and normative regulation}

The social life of the neighbourhood has been approached in the literature from at least four perspectives. First, the Durkheimian approach (Thorlindsson and Bernburg, 2004; Paugam et al., 2009) builds on early Durkheim's concepts of integration and regulation, the former referring to social interaction and bonds, the latter to norms and control. Second, the concept of social disorganisation has been central in the Chicago tradition of urban sociology. This concept associates structural neighbourhood factors - originally poverty, residential instability and racial/ethnic heterogeneity - to juvenile delinquency (Shaw \& McKay, 1942), or more generally, neighbourhood disadvantage to problems of social order. The theoretical explanation for this is that neighbourhood disadvantage undermines normative consensus, strong bonds and interaction among the residents with the consequence of inefficient informal social control (Sampson and Groves, 1989; Sampson et al., 1997; Bellair and Browning, 2010; Kubrin, 2010; cf. Sutherland et al., 2013). Third, the concept of social capital has been discussed also in urban studies (e.g. Henning and Lieberg, 1996; Boyce, 2006). Halpern (2005) defines social capital in terms of networks, norms and sanctions, with bonding, bridging and linking functions. In urban applications, especially the community-level bonding and bridging capital - or strong and weak ties - have received attention. Fourth, Kearns and Forrest (2000) describe the dimensions of cohesive urban society, which are common values and norms, social order and control, social solidarity and equality, networks and social capital, and territorial belonging.

Nuanced differences notwithstanding, all the presented frameworks share the dual focus on the social integration (interaction, bonds, networks, ties) and normative regulation (informal social control, norms, values, sanctions). Adopting this distinction, also we follow here this approach when we conceptualise the social mechanisms linking the structural features of estates to the level of social disorder.

\section{Prior findings and present study}

Problem focus is characteristic for the estate literature, which has documented vicious circles of social breakdown (Power, 1997) and the trajectories of problematic estates (Tunstall and Coulter, 2006; Wassenberg, 2013; cf. Stjernberg, 2015). Most of the contemporary European large-scale studies stem from the RESTATE project, targeting 31 post-WWII housing estates across Europe which were selected due to problems. These estates are characterised by physical problems stemming from low quality construction, weak position in the housing markets (especially in the North and West of Europe), high unemployment, poorly maintained public spaces and safety problems. Furthermore, their populations are aging and increasingly heterogeneous in ethnic terms. (Dekker and van Kempen, 2004.) While a large number of residents of the RESTATE survey are satisfied with their estate, there is a considerable share of those who are dissatisfied and feel trapped (Musterd and van Kempen, 2007).

In addition to the RESTATE project, an older study by Skifter Andersen (2003) is highly relevant in this context. Using data from the 1990s, the study examined a large number of Danish housing estates and found that large size, the degree of urbanisation, low level of social activities, poor quality of the physical environment and socio-economic disadvantage of the estate predict the level of social problems or disorder. It is, however, unclear how estates were operationally defined and how well the results apply to the contemporary situation. These findings are in line with the more general 
urban sociological literature, where neighbourhood disadvantage is one of the most established factors predicting disorder (e.g. Sampson and Raudenbush, 1999; Ceccato and Haining, 2005).

A more recent study from the Helsinki region (Kemppainen \& Saarsalmi, 2015) found that perceived social disorder was most common in the estates built in the 1960s and 1970s, almost as common in other multi-storey areas, and clearly least common in low-rise neighbourhoods. Furthermore, it was found that low income level and high unemployment predict higher level of perceived disorder. Disparities in socio-economic disadvantage also explained why estate neighbourhoods did slightly worse in terms of disorder compared with other multi-storey areas. Besides estate literature, the study by Kearns and Mason (2007) on British wards merits attention due to its focus on tenure. The study found that neighbourhood crime and disorder, measured by survey, vary with tenure structure quite linearly in such a way that a higher proportion of social housing corresponds to higher prevalence of perceived problems. Owner-occupied neighbourhoods show the lowest level of problems, and mixed ones are between the two extreme poles.

All in all, there is scarcity of contemporary large-scale evidence on social disorder in post-WWII estates. Moreover, the prior estate literature is mainly based on case studies or on a group of estates chosen on the basis of problems. In order to elucidate the situation and variation of estates, a different approach is used in our study, based on a large cluster sample covering the entire social and geographical variety of estates in the country. Importantly, this kind of approach enables us to examine the variation in tenure structure and its implications for social order, since tenure policy has taken different forms depending on the city region in question. On the other hand, Kubrin (2010) has called for further research on disorganisation theory with survey indicators instead of police or court data, with better neighbourhood definitions, and with a focus on forces beyond the neighbourhood community. The present study addresses these issues by utilising survey indicators of disorder, focusing on neighbourhoods that are distinct due to their architectural design and hence provide a fairly robust neighbourhood definition, and by examining the role of tenure policy - a force transcending the neighbourhood limits - in shaping the local social life. Finally, Kearns and Mason (2007) suggest that future studies on mixed tenure should take into account certain key factors their study could not address, such as the built environment, social composition of the neighbourhood and the location of a neighbourhood in the wider urban structure. They also consider that the topic should be analysed at a smaller spatial scale than theirs, as wards are relatively large spatial units. All of the mentioned issues are accounted for in the present study.

Our research questions and hypotheses are as follows:

1) How is the tenure structure of the estate related to perceived social disorder? Does local social disadvantage mediate the association? (RQ1)

The context of the present study, Finland, is considered a home-owning society (Ruonavaara, 1987): currently around two-thirds of the apartments are owner-occupied (Statistics Finland, 2013). Historically, detached owner-occupied housing has had a highly valued ideological position (Ruonavaara, 1987; Ruonavaara, 1996; Andersson et al., 2007). The rental market is dualised into a 
relatively unregulated private market and a means-tested social housing sector with a negative 'welfare housing' image (Andersson et al., 2007). On the basis of the results by Kearns and Mason (2007), we expect that rental-dominated tenure structure predicts higher disorder. We hypothesise that this is mainly because rental tenure, especially social housing, is associated with social disadvantage; rental tenure is, after all, often the only choice for the less affluent households (see Hirvonen et al., 2014). Following disorganisation tradition, there are grounds to expect that social disadvantage of the estate predicts higher disorder. Hence it should strongly mediate the tenuredisorder association.

2) To what extent do social interaction and normative regulation of the estate explain why more disadvantaged estates expose their residents to social disorder? (RQ2)

On the one hand, the collective efficacy variant of disorganisation theory highlights the role of normative regulation as a central mechanism linking structural disadvantage to social disorder (Sampson et al., 1997). Thus, we expect that regulation considerably mediates the impact of estatelevel disadvantage. On the other hand, neighbourhood disadvantage can break solidarity and lead to internal distinctions, undermining integration (Paugam, 2011). Social interaction may foster informal social control and, hence, curb social disorder. Thus, it is possible that local social interaction plays a role in the association of disadvantage and the perceptions of social disorder. However, disadvantage may in some cases form a basis for local collective identity, social support and strong social relationships between neighbours (Boyce, 2006). If this is the case, the role of interaction is more complex.

\section{Data, variables and methods}

Data

Our hierarchical two-level dataset combines information from a large-scale survey targeting suburban housing estate residents (the PREFARE project funded by the Academy of Finland) with corresponding geographically aggregated register data from the Grid Database (Ruututietokanta, version 2009). The latter is a database aggregated to statistical grids $(250 \mathrm{~m} \times 250 \mathrm{~m}$ ) by Statistics Finland (2014), and it provides information on the demographic, socio-economic and housing structure of the grids. Our survey targeted the 25-74 year-old Finnish-speaking residents of the multi-storey buildings of Finnish suburban housing estates. ${ }^{1}$ These neighbourhoods were identified with the help of geographically referenced coordinate-based statistical data. Technically, they consist of one or more adjacent grids, and the estate-level register information is obtained by merging that of the constitutive grids. We defined housing estates using the following criteria:

i) location outside of the main centres of Finnish cities;

ii) at least half of the total population lives in multi-storey apartment buildings constructed during the 1960s and 1970s;

iii) at least five of these specific buildings are situated within a close range (a maximum distance of 250 meters) from each other.

\footnotetext{
${ }^{1}$ Due to financial considerations, we limited our target population to the Finnish-speaking residents, thus excluding most of the immigrant population.
} 
Furthermore, a lower limit to the population size was defined (at least 300 residents) in order to capture a certain degree of urbanity and a sufficient sample size. In total, there are 318 such estates in the country.

The sampling design of our survey was a stratified two-stage cluster sample. The objective of the stratification was to ensure that the sample would cover the entire range of different kinds of estates and it was based on the level of unemployment in an estate and the population size of the corresponding municipality. In addition, five well-known disadvantaged estates were chosen for the purposes of in-depth case studies; each of them constitutes a stratum of its own, which deflates their weights correspondingly.

In total, 71 clusters (estates) were selected out of the 318 clusters, using stratified random sampling. The size of target population in these 71 estates was 51 028, of which a random sample of 19844 was drawn. The data were collected in 2013 with a response rate of 39 per cent. A multivariate logistic non-response model showed that male gender, young age, low education, low income and rental tenure predict lower response propensity (cf. Laaksonen et al., 2015). Our final weights account for varying inclusion probabilities at both levels and response propensities at the individual level, thus counteracting the problem of non-response as well as possible. There are, on average, 109 respondents per estate, with the standard deviation of 59 (range: 14-298). The estate with only 14 respondents was excluded from the analyses due to its small $n$ at level-1. The other 70 estates have in minimum 35 respondents per estate.

\section{Outcome variable: perceived social disorder}

The outcome variable perceived social disorder was constructed by a factor analysis of eight survey items on the perceptions of the following events or signs in the neighbourhood: public drunkenness, vandalism, uncleanliness, neighbours causing disturbance, drug use or trade, threatening behaviour, thefts and poorly managed buildings and yards (four-point scale on the amount of perceptions, extending from none to a lot). The set of items shows remarkable internal consistency (Cronbach's Alpha $=0.88$ ) and the score of dominant factor (initial Eigenvalue 4.28) was extracted by the maximum likelihood method. We did not define neighbourhood to the respondents, but in the case of post-WWII estates the rather distinctive built environment is likely to strengthen the shared understanding of the concept. Our empirical results support this view, since the intra-class correlation of the factor score is 0.21 , which tells about a considerable intra-estate agreement.

To illustrate what our outcome measure means in practical terms, we describe it next by its key components. We also report important bivariate associations with other relevant measures. First, we divided estates into three equal groups on the basis of their mean level of perceived social disorder. In the low disorder estates, around $11 \%$ of the respondents have perceived at least some public drunkenness in the neighbourhood, while the rate is almost $60 \%$ in the high disorder estates. The corresponding figures are $14 \%$ and $54 \%$ for vandalism, $3 \%$ and $16 \%$ for drug use or trade, and $2 \%$ and $15 \%$ for threatening behaviour. Second, in unadjusted random intercept models, higher individual-level perceptions of social disorder predict lower affective attachment to the 
neighbourhood; lower assessment of the reputation of the neighbourhood; higher level of subjective insecurity in the neighbourhood; more frequent experiences of seeing violence, being threatened by violence, being victim of violence and theft or vandalism; heightened intention to move away from the neighbourhood; and lower self-rated health. Also, the estate-level mean of perceived social disorder predicts contextually all these outcomes in a similar fashion. All these results are individually statistically significant $(p<0.05) .^{2}$

\section{Predictors}

Tenure structure of the estate was operationalised using two variables. First, we constructed a variable on the proportion of rental apartments of all apartments, using the estate-level register data. In the Grid Database, the category rental includes social and private rental housing and the so-called right-of-occupancy tenures. Hence, an additional proxy for social rental housing was constructed using survey data; estates were divided into three groups on the basis of the share of social-rental-dwelling respondents of all rental-dwellers, using 25 and $75 \%$ as cut-offs.

In addition to these two estate-level contextual indicators, we measure the tenure type also at the respondent level. Owner-occupied and social rental apartments are often located in separate buildings, whereby this seemingly individual indicator has also a contextual aspect to it. There is a more micro-level emphasis in this indicator, enabling a more nuanced analysis of the spatial scale of the tenure basis.

Socio-economic disadvantage of the estate was operationalised as a latent variable, based on a factor analysis of education, income and unemployment in the estate. The education level of the estate was measured by the proportion of the tertiary educated of the population aged 18 years or more. Income level was operationalised using the share of the earners with low income of all income earners (gross individual income less than 14,000 EUR/year). In addition to being a central measure of socio-economic disadvantage, unemployment also constitutes an important local population group, present in the neighbourhood also during the standard working time, which is why we wanted to indicate their proportion in relation to the entire population size of the estate. A latent variable approach was adopted because these variables correlate strongly with each other (the absolute values of correlations range from 0.57 to 0.72 ).

The indicators of local social life were obtained from a single factor analysis of the individual-level survey responses on items that were expected to measure social interaction and normative regulation in the neighbourhood. First, the items explicitly tapping social interaction in the neighbourhood were: how often the respondent talks with neighbours; makes visits in the neighbourhoods; gives or receives help to/from neighbours; co-operates with neighbours in the matters of their house or environment; or meets neighbours in associational activities (five-point scale from never to daily).

\footnotetext{
${ }^{2}$ Except for the contextual model of violent victimisation, these findings remain statistically significant after adjustments for gender, age, education, occupational position, household income, and household type of the respondent, as well as the logged population size of the estate.
} 
Second, normative regulation was approached following Sampson et al. (1997), who conceptualise collective efficacy in terms of two sub-concepts, social cohesion and informal social control. Social cohesion was measured by five items on the level of normative consensus in the neighbourhood: people are willing to help each other in the neighbourhood; can be trusted; and share the same values; this is a close-knit neighbourhood; people don't get along with each other in the neighbourhood (five-point scale Likert-type scale from total agreement to total disagreement). Also informal social control followed closely the operationalisation of Sampson et al. (1997) with some modifications to make the measurement better suit the focus and context of our study. The items asked the respondent to estimate the probability that the people in their neighbourhood would intervene in the following situations: youth skipping school and hanging out in the neighbourhood; someone spray-painting graffiti or vandalising a local building; youth behaving inappropriately towards an adult; a fight in front of their house; drunken disturbance; and disturbing noise at night in a local apartment (five-point scale from very improbable to very probable).

The latent structure of the factor analysis followed our expectations, as the three concepts constituted clearly dimensions of their own, with Alphas ranging between 0.78 and 0.88 . Varimax rotation was used in order to analytically disentangle the three components from each other at the level of individual perceptions. In the regression models, we used the corresponding contextual variables, which were constructed as weighted estate-level averages of the individual factor scores.

Following the suggestion of Kearns and Mason (2007), we incorporated also physical and locational aspects in our analyses. As the estates are relatively similar in terms of the built environment, we were able to approach the physical aspect in a very specific way, by examining the role that the height of the buildings plays in terms of social order. By using housing register data, we classified houses into three categories: two to four; five to seven; and eight or more storeys. Furthermore, we calculated the average building height in the estate.

The locational perspective was operationally incorporated into the analyses by two variables. The first of them indicates the type of the wider urban structure where the estate is located and includes the classes of Helsinki metropolitan area, bigger cities (Tampere and Turku), medium-sized cities (80,000200,000 inhabitants) and others (Ristimäki et al., 2013). The other one measures regional development on the basis of the change in the population between 1990 and 2010. Using the cut-off points of minus five and five per cent, the regions were classified into growing, stable and shrinking.

Demographic composition of the estate was operationalised using factor analysis of three variables on household structure and eight variables on the proportions of different age groups. The information of these eleven variables could be reduced to two dimensions, which differentiate the estates by the proportions of 1) families with children, and 2) young adults and single households.

Direct indicators of residential instability were not available in the register data, which is why we calculated a proxy using survey data, indicating the share of residents having lived in the estate for less than one year. There was no available information on the ethnic structure of the grids, which was unfortunate due to its theoretical significance. 
Also population size (logarithm) was controlled for.

Individual level control variables are gender, age categories, education (basic, secondary and tertiary), occupational status, household type and net household income, and the time one has lived in the current neighbourhood.

\section{Methods}

Linear random intercept models were estimated with a procedure mixed in Stata, which enables the correct use of survey weights at both levels. In order to examine the role of estate-level social interaction and normative regulation (RQ 2), we randomised the respondents into two equal subsets. We used one of the subsets to aggregate the survey responses on social interaction and normative regulation into corresponding estate variables. Then we merged these results with the other subset, with which we estimated the regression models. This way, the information on the local social life was extracted from different respondents than the information on outcome, which solves the problem of potential individual-level confounding between the outcome and the assessment of neighbourhood's social properties.

\section{Results}

\section{Descriptive findings}

There is a substantial degree of variation between estates in many respects including the proportion of rental apartments, share of social rental apartments, population size as well as the survey measures of local social life - especially perceived social disorder (Table 1). 
Table 1. Descriptive statistics.

\begin{tabular}{|c|c|c|c|c|}
\hline & Mean / \% & SD & Min & Max \\
\hline \multicolumn{5}{|l|}{ OUTCOME $(n=7603)$} \\
\hline Perceived social disorder (factor score) & 0.00 & 1.00 & -1.45 & 3.64 \\
\hline \multicolumn{5}{|l|}{ ESTATE VARIABLES $(n=70)$} \\
\hline 'erceived social disorder (factor score, estate-mean *) & -0.04 & 0.50 & -0.98 & 1.29 \\
\hline Rental / all apartments & 0.48 & 0.19 & 0.17 & 1.00 \\
\hline Social rental / rental apartments & 0.49 & 0.30 & 0.00 & 0.99 \\
\hline Socio-economic disadvantage (factor score) & 0.00 & 1.00 & -2.90 & 2.06 \\
\hline Social interaction (factor score, estate-mean ${ }^{*}$ ) & -0.04 & 0.18 & -0.48 & 0.39 \\
\hline Social cohesion (factor score, estate-mean ${ }^{*}$ ) & -0.04 & 0.25 & -1.12 & 0.44 \\
\hline Informal social control (factor score, estate-mean ${ }^{*}$ ) & 0.02 & 0.17 & -0.35 & 0.42 \\
\hline Average number of storeys & 4.72 & 1.45 & 2.40 & 10.29 \\
\hline Urban structure: Helsinki region (\%) & 40.00 & . & . & . \\
\hline - Big cities (\%) & 18.60 & . & . & . \\
\hline - Medium cities (\%) & 17.10 & . & . & . \\
\hline - Other (\%) & 24.30 & . & . & . \\
\hline Regional development: Growing (\%) & 74.30 & . & . & . \\
\hline - Stable (\%) & 12.90 & . & . & . \\
\hline - Shrinking (\%) & 12.90 & . & . & . \\
\hline Age structure: families with children (factor score) & 0.01 & 1.00 & -2.79 & 2.20 \\
\hline Age structure: young adults (factor score) & -0.07 & 0.80 & -1.58 & 2.01 \\
\hline Residential instability & 0.06 & 0.03 & 0.00 & 0.14 \\
\hline Population & 1895.14 & 1996.01 & 403.00 & 11951.00 \\
\hline
\end{tabular}

$(*)$ : estate means were aggregated using response-propensity adjusted sampling weights

We examined next the bivariate relationship between tenure structure and socio-economic and social indicators. We divided our housing estates into ten deciles on the basis of proportion of rental apartments (cf. Kearns and Mason, 2007). Table 2 describes them in socio-economic and social terms.

Quite interestingly, the proportion of social rental apartments out of all rental apartments increases with the overall share of rental apartments. In the most owner-occupied decile, around one fifth of the apartments are rental ones, of which again one fifth are social rental. In the most rental dominated decile, both proportions are about $90 \%$. The share of low income earners varies quite consistently with tenure structure, ranging from $30 \%$ to $43 \%$. The same applies to unemployment, and education, albeit the relationship is somewhat less clear in the latter case. From the point of view local social life, perceived social disorder, social cohesion and informal social control are expectedly and strongly associated to tenure structure. In contrast, social interaction is not linearly related to the tenure basis. The most mixed estates seem to fare rather well in terms of interaction, which is noteworthy regarding the debate on social mixing. Strikingly, the most rental-dominated decile clearly differs from the others in most of the indicators. 
Table 2. Association between the share of rental housing and socio-economic and social characteristics of estates.

\begin{tabular}{|c|c|c|c|c|c|c|c|c|c|}
\hline \\
\hline Decile & $\begin{array}{c}\text { Rental / } \\
\text { all } \\
\text { apart- } \\
\text { ments }\end{array}$ & $\begin{array}{c}\text { Social } \\
\text { rental / } \\
\text { rental } \\
\text { apart- } \\
\text { ments }\end{array}$ & $\begin{array}{l}\text { Low } \\
\text { income }\end{array}$ & $\begin{array}{l}\text { Tertiary } \\
\text { edu- } \\
\text { cation }\end{array}$ & $\begin{array}{l}\text { Unemp- } \\
\text { loyed }\end{array}$ & $\begin{array}{c}\text { Perceived } \\
\text { social } \\
\text { disorder } \\
\left(^{*}\right)\end{array}$ & $\begin{array}{l}\text { Social } \\
\text { inter- } \\
\text { action } \\
(*)\end{array}$ & $\begin{array}{c}\text { Social } \\
\text { cohesion } \\
(*)\end{array}$ & $\begin{array}{c}\text { Informal } \\
\text { social } \\
\text { control } \\
(*)\end{array}$ \\
\hline 1 & $21.9 \%$ & $20.8 \%$ & $30.3 \%$ & $12.4 \%$ & $4.8 \%$ & -0.47 & -0.06 & 0.15 & 0.06 \\
\hline II & $28.7 \%$ & $33.6 \%$ & $28.0 \%$ & $17.8 \%$ & $4.7 \%$ & -0.28 & -0.07 & 0.09 & 0.13 \\
\hline III & $35.2 \%$ & $32.5 \%$ & $33.5 \%$ & $16.5 \%$ & $4.9 \%$ & -0.31 & 0.00 & 0.07 & 0.06 \\
\hline IV & $40.3 \%$ & $32.1 \%$ & $34.4 \%$ & $14.9 \%$ & $6.0 \%$ & -0.36 & -0.07 & 0.10 & 0.07 \\
\hline V & $43.8 \%$ & $42.2 \%$ & $39.8 \%$ & $9.6 \%$ & $8.2 \%$ & -0.04 & 0.10 & -0.02 & 0.14 \\
\hline $\mathrm{VI}$ & $46.4 \%$ & $53.3 \%$ & $43.6 \%$ & $9.7 \%$ & $8.4 \%$ & 0.00 & 0.02 & -0.09 & -0.05 \\
\hline VII & $50.3 \%$ & $62.3 \%$ & $36.2 \%$ & $12.7 \%$ & $6.3 \%$ & 0.06 & -0.01 & -0.05 & 0.04 \\
\hline VIII & $55.6 \%$ & $57.7 \%$ & $40.6 \%$ & $10.7 \%$ & $7.0 \%$ & 0.15 & -0.11 & -0.12 & 0.01 \\
\hline $\mathrm{IX}$ & $65.7 \%$ & $71.7 \%$ & $43.0 \%$ & $13.9 \%$ & $8.0 \%$ & 0.16 & -0.08 & -0.18 & -0.02 \\
\hline $\mathrm{X}$ & $89.9 \%$ & $87.6 \%$ & $42.9 \%$ & $6.5 \%$ & $8.6 \%$ & 0.69 & -0.13 & -0.36 & -0.20 \\
\hline Total & $47.8 \%$ & $49.4 \%$ & $37.2 \%$ & $12.5 \%$ & $6.7 \%$ & -0.04 & -0.04 & -0.04 & 0.02 \\
\hline \multicolumn{10}{|c|}{ Note: higher values indicate higher disorder, interaction etc. in the factor variables. } \\
\hline & & & & & & & & & \\
\hline \multicolumn{10}{|c|}{$\begin{array}{l}(*) \text { : estate mean of the factor score, aggregated using response-propensity adjusted } \\
\text { sampling weights }\end{array}$} \\
\hline
\end{tabular}

As a conclusion of the descriptive examination and as a partial response to RQ1, tenure structure is related quite logically to socio-economic disadvantage and perceived social disorder. The relationships between these three factors are elaborated next in more detail in a cross-sectional multivariate framework. The descriptive analysis suggests that a continuous measurement of the tenure structure should do well for this purpose. Non-linearity and the possible exceptionality of the $10^{\text {th }}$ decile will be assessed, respectively, testing a square term and a separate indicator variable.

\section{Regression models}

Regression analysis was carried out in the order of the research questions. First we examined the relationship of tenure structure and perceived social disorder (PSD) by controlling for potential confounders and studying how socio-economic structure mediates the relationship (RQ 1), which is followed by an analysis of the social mechanisms at play (RQ 2).

In an unadjusted model, the tenure structure of the estate is a strong predictor of PSD and explains around half of its variation between estates (Table 3, Model I). Tenure structure of the estate matters in two ways. First, the more there is rental housing in the first place, the higher is the level of PSD. Moreover, a higher share of social rental housing within the rental sector predicts higher PSD: in the estates with the highest share of social housing, the level of perceived social disorder is 0.68 units (i.e. standard deviations) higher compared to those dominated by owner-occupied housing. The square term of the rental proportion and the separate indicator variable for the tenth decile do not have any 
independent power in this model (not shown in tables). Hence, the relationship between rental proportion and PSD is modelled linearly.

Next we controlled for potential confounders at both levels (Model II), which attenuates the estimates of social housing variables. Nevertheless, the tenure structure remains a significant predictor of PSD even after these relatively stringent adjustments. In addition, private rental ( $B=0.15$, $p<0.0005)$ and especially social rental tenure $(B=0.34, p<0.0005)$ of the respondent strongly predict PSD in model II, including both of these individual-level tenure variables. This means that tenure operates at multiple spatial scales at the same time. In sum, there is something in the tenure structure that patterns the experiences of PSD, independent of the other predictors in Model II.

The next question concerns the role of the socio-economic situation of the estate. As we saw in the descriptive analysis, tenure structure is quite logically related to socio-economic indicators, which further strengthens our expectation that disadvantage should be a strong mediator. As it turned out, also the results support the hypothesis, since the latent estate-level variable measuring socioeconomic disadvantage strongly predicts PSD and completely attenuates the coefficients of estatelevel tenure structure variables (Model III).

Taken together, these factors explain almost ninety per cent of the unadjusted between-estates variation in PSD: the estate-level variance component of the null model is 0.206 , which is reduced to 0.031 in Model III. Before proceeding, let us have a look at other contextual predictors of Model III. The population size of the estate and its location within the urban structure of the Helsinki region predict PSD. The physical environment does not differentiate housing estates from the perspective of social order, since neither the estate-level mean of the building height nor the height of the respondent's building predicts PSD. Neither does residential instability have independent predictive power.

Reducing the theoretically unnecessary and empirically redundant contextual predictors enhances the analytic power at the estate level at which the degrees of freedom are limited. Concerning the urban structure variable, the reference class (Helsinki region) was brought in as an indicator of its own and the other classes were omitted in order to efficiently model the most important distinction. The average building height, age structure factor related to the proportion of young adults, regional development dummies and the variable on residential instability were omitted one by one, on the basis of predictive power. As a consequence, the share of families with children turned out to be independently associated with PSD $(B=0.08, p=0.002)$. The more there are families of this kind, the more residents perceive social disorder. 
Table 3. Random intercept models of perceived social disorder (RQ 1). Results of contextual variables. Full data. (a)

\begin{tabular}{|c|c|c|c|c|c|c|c|c|}
\hline Model number & \multicolumn{2}{|r|}{0} & \multicolumn{2}{|r|}{ I } & \multicolumn{2}{|r|}{ II } & \multicolumn{2}{|r|}{ III } \\
\hline \multirow[t]{2}{*}{ Description } & \multicolumn{2}{|c|}{$\begin{array}{l}\text { Null / variance } \\
\text { components }\end{array}$} & \multicolumn{2}{|c|}{ Tenure } & \multicolumn{2}{|c|}{$\begin{array}{c}\text { Tenure + controls } \\
\text { (a) }\end{array}$} & \multicolumn{2}{|c|}{$\begin{array}{l}\text { Tenure + controls } \\
\text { + estate SES (a) }\end{array}$} \\
\hline & B & s.e. (sig.) & B & s.e. (sig.) & B & s.e. (sig.) & B & s.e. (sig.) \\
\hline Rental / all apartments & . & . & 0.77 & $0.34 *$ & 0.80 & $0.29 * *$ & 0.18 & 0.29 \\
\hline $\begin{array}{l}\text { Social rental / rental } \\
\text { apartments (ref: Low) }\end{array}$ & • & $\cdot$ & & . & • & - & - & . \\
\hline - Mid & . & . & 0.34 & $0.08 * * * *$ & 0.14 & 0.09 & 0.07 & 0.08 \\
\hline - High & . & . & 0.68 & $0.15 * * * *$ & 0.26 & $0.11 *$ & 0.14 & 0.12 \\
\hline Population (log) & . & . & . & . & 0.45 & $0.10 * * * *$ & 0.33 & $0.08 * * * *$ \\
\hline $\begin{array}{r}\text { Age structure: families with } \\
\text { children (factor) }\end{array}$ & • & . & . & . & 0.11 & $0.04 * *$ & 0.06 & 0.03 \\
\hline $\begin{array}{r}\text { Age structure: young adults } \\
\text { (factor) }\end{array}$ & - & . & • & . & -0.01 & 0.05 & 0.03 & 0.04 \\
\hline Residential instability & & & & & -1.77 & $0.88 *$ & -1.18 & 0.86 \\
\hline Average number of storeys & . & . & . & . & 0.00 & 0.02 & 0.00 & 0.02 \\
\hline $\begin{array}{r}\text { Urban structure (ref: } \\
\text { Helsinki region) }\end{array}$ & · & - & . & . & . & . & . & . \\
\hline - Big cities & . & . & . & . & 0.00 & 0.09 & -0.36 & $0.11 * * *$ \\
\hline - Medium cities & . & . & . & . & -0.15 & 0.10 & -0.48 & $0.10 * * * *$ \\
\hline - Other & . & . & . & . & -0.11 & 0.11 & -0.40 & $0.12 * * *$ \\
\hline $\begin{array}{r}\text { Regional development (ref: } \\
\text { Shrinking) }\end{array}$ & • & $\cdot$ & $\cdot$ & $\cdot$ & $\cdot$ & $\cdot$ & . & $\cdot$ \\
\hline - Stable & . & . & . & . & 0.01 & 0.16 & 0.16 & 0.11 \\
\hline - Growing & . & . & . & . & -0.06 & 0.14 & 0.15 & 0.12 \\
\hline $\begin{array}{r}\text { Socio-economic } \\
\text { disadvantage }\end{array}$ & . & . & . & . & . & . & 0.26 & $0.04 * * * *$ \\
\hline Intercept & -0.11 & $0.06 *$ & -0.76 & $0.13 * * * *$ & -2.08 & $0.35 * * * *$ & -1.32 & $0.29 * * * *$ \\
\hline $\mathrm{n}$ & & 7603 & & 7603 & & 7553 & & 7553 \\
\hline $\begin{array}{r}\text { Variance components: } \\
\text { estate }\end{array}$ & & 0.206 & & 0.097 & & 0.049 & & 0.031 \\
\hline $\begin{array}{r}\text { Variance components: } \\
\text { individual }\end{array}$ & & 0.766 & & 0.766 & & 0.719 & & 0.719 \\
\hline
\end{tabular}

Note: $* \mathrm{p} \leq 0.05, * * \mathrm{p} \leq 0.01,{ }^{* * *} \mathrm{p} \leq 0.001, * * * * \mathrm{p} \leq 0.0005$

(a): the following respondent-level variables were controlled for in models 2 and 3: age, gender, education, income, occupational status, time one has lived in the neighbourhood, household type, tenure and building height

We studied next the interaction between respondent's social rental tenure and the estate-level disadvantage. In theory, it could be the case that social housing buildings are relatively stable hotspots of PSD, independent of the surrounding neighbourhood. On the other hand, the total impact 
of estate disadvantage and social rental tenure may be simply cumulative - in other words, there would be nothing special about social housing. We added an interaction term in the reduced model to empirically examine this topic. The result was strongly significant statistically ( $p$-value of the term 0.009 ) and it is best interpreted through visualisation. As we see in Figure 1, socio-economic disadvantage of the entire estate does indeed matter also for those living in social housing. In fact, it matters more than for others. This may be partly due to the fact that the disadvantage of the social housing population correlates positively with that of the larger estate. In sum, the social housing environment seems to be a sensitive hot-spot of disorder, varying in intensity with the overall disadvantage of the estate.

Summing up our findings to the first research question, rental domination of the estate coincides with local socio-economic disadvantage, which is translated into residents' experience as heightened levels of social disorder. A more mixed tenure alleviates local disadvantage and, as a result, ameliorates local social order.

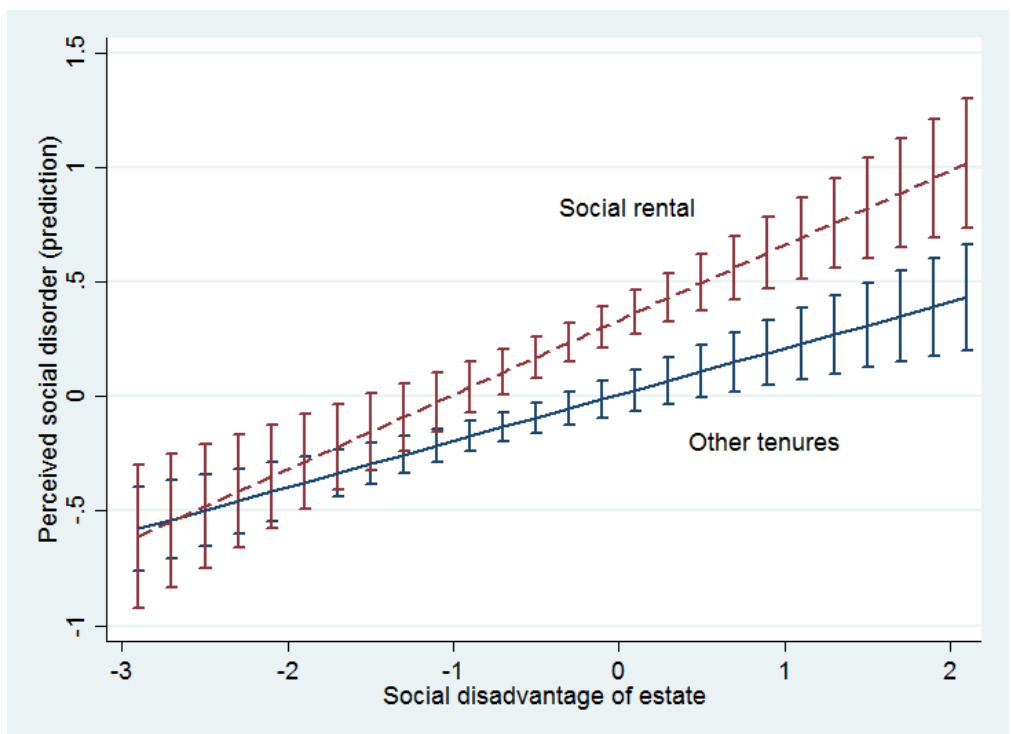

Figure 1. Predicted values of perceived social disorder. Interaction between individual tenure and estate disadvantage. $95 \%$ confidence intervals.

Next, what are the social mechanisms at play in the association between disadvantage and disorder? (RQ 2) As explained in the methods section, in the following analysis we use split data.

The reduced model was further simplified by removing estate tenure from the predictors, as it was no longer theoretically or empirically necessary at this stage. This gave us our starting point (Table 4, Model IV). We added first the estate-level social interaction to Model IV, but it turned out to be nonsignificant ( $p=0.646$ ) and made no changes to the estimates (not shown in tables). Hence, it was excluded from the model. Next, we introduced social cohesion and informal social control (Model V). It shows that both of these components of collective efficacy strongly predict PSD and substantially attenuate the coefficient of estate-level disadvantage. In practice, in the more disadvantaged estates 
there is less normative consensus and lower expectations of informal social control, which leaves more room for disorder. However, it should be observed that disadvantage remains a strong predictor in the final model. Consequently, it operates also through other pathways than those captured by our measures of social mechanisms.

Table 4. Random intercept models of perceived social disorder (RQ 2). Results of contextual variables. Split data. (a)

\begin{tabular}{|c|c|c|c|c|}
\hline \\
\hline Model number & \multicolumn{2}{|c|}{ IV } & \multicolumn{2}{|c|}{$\mathbf{v}$} \\
\hline \multirow[t]{2}{*}{ Description } & \multicolumn{2}{|c|}{ Starting point } & \multicolumn{2}{|c|}{ Final } \\
\hline & B & s.e. (sig.) & B & s.e. (sig.) \\
\hline Population (log) & 0.40 & $0.09 * * * *$ & 0.40 & $0.07^{* * * *}$ \\
\hline $\begin{array}{r}\text { Age structure: families with children } \\
\text { (factor) }\end{array}$ & 0.10 & $0.02 * * * *$ & 0.08 & $0.02 * *$ \\
\hline Urban structure: Helsinki region & 0.39 & $0.10 * * * *$ & 0.24 & $0.09 * *$ \\
\hline Socio-economic disadvantage & 0.27 & $0.04^{* * * *}$ & 0.19 & $0.04 * * * *$ \\
\hline Social cohesion & . & & -0.33 & $0.16^{*}$ \\
\hline Informal social control & & & -0.34 & $0.11 * *$ \\
\hline Intercept & -1.74 & $0.27^{* * * *}$ & -1.68 & $0.23 * * * *$ \\
\hline $\mathrm{n}$ & \multicolumn{2}{|c|}{3745} & \multicolumn{2}{|c|}{3745} \\
\hline Variance components: estate & \multicolumn{2}{|c|}{0.041} & \multicolumn{2}{|c|}{0.032} \\
\hline Variance components: individual| & \multicolumn{2}{|c|}{0.705} & \multicolumn{2}{|c|}{0.705} \\
\hline
\end{tabular}

Note: ${ }^{*} \mathrm{p} \leq 0.05, * * \mathrm{p} \leq 0.01, * * * \mathrm{p} \leq 0.001, * * * * \mathrm{p} \leq 0.0005$

(a): the following respondent-level variables were controlled for in all models: age, gender, education, income, occupational status, time one has lived in the neighbourhood, household type, tenure and building height

Adding social interaction to Model V makes no changes to the results. Also keeping the estate tenure structure in the model leaves the results basically the same. From the point of view of substantial interpretations, including social cohesion and informal social control separately on top of Model IV gives same kind of results as Model V.

To sum up our results on the second research question, we found that the measures of collective efficacy, which theoretically indicate normative regulation, considerably mediate the association between estate-level disadvantage and PSD. In contrast, social interaction is not involved in this association.

\section{Discussion}

Using survey and register data on 70 post-WWII housing estates, we examined the relationship between tenure structure and residents' perceptions of social disorder. We found that rental and especially social rental domination of the estate exposes residents to social disorder, because this kind of tenure structure is associated with contextual social disadvantage. In line with social disorganisation theory, contextual disadvantage was found to be related to perceived social disorder. 
A partial explanation of this is that disadvantage is associated with lower normative regulation. The more disadvantaged estates are characterised by lower normative consensus and weaker informal social control, which creates a suitable ground for social disorder; however, most of the disadvantage-disorder association was not mediated by these factors.

In a European comparison, Finnish cities can be considered rather safe and signs of deprivation are not conspicuous. However, relative differences matter and they are known to the relevant actors. Perceptions of disorder - and reputation of it - are important in terms of residential preferences and moving behaviour. Combined with the regional differences in economic and demographic prospects, this implies that the overall differentiation of post-WWII estates is likely to increase. The extent of this differentiation is not yet easy to predict, but the more general development of social inequalities will have a central role in this regard.

According to our findings, social interaction in the neighbourhood does not differentiate housing estates in terms of social order, which is a finding that merits discussion. These results contradict the systemic variant of social disorganisation model, emphasising the role of local social ties, but they are in line with studies highlighting the role of normative consensus and control expectations (Sampson and Raudenbush, 1999). While the normative aspect of neighbourhood life does not seem to depend on social interaction, it is strongly dependent on social disadvantage of the neighbourhood. Social interaction may possibly mediate different information in different socio-economic contexts and contribute this way to normative regulation in some contexts only. From this point of view, it would be the content, not the level of social interaction in itself that matters (cf. Bellair \& Browning, 2010). At any rate, there is a plausible practical implication to our finding: initiatives that aim to strengthen neighbourhood interaction may not necessarily result in positive changes in regulation and order, even if successful and otherwise beneficial.

Our results also contribute to the debate on social mixing, and provide evidence on mixed tenure in the context of Nordic welfare states (cf. Sautkina et al., 2012). Compared to the most rental dominated estates, the level of perceived disorder is lower in those estates where tenure structure is more balanced. This is because tenure structure has an expected relationship with contextual social disadvantage. From this point of view, a more mixed tenure is a preferable option when new areas are planned and possibly also when older ones are being developed. However, a remarkable difference with respect to the tenure debate is that in Finland mixing was built in from the very beginning instead of renovation afterwards. Tenure mixing may have different implications depending on when it is implemented.

It is well-known that causal inference cannot be optimally backed with cross-sectional data alone. First, it is likely that there is a complex web of back- and-forth impacts between disorder, cohesion and control. Theoretically, not only does lower social control pave way for more disorder, but also disorder may impact back at cohesion and also willingness to perform acts of control. This may happen, for example, through fear, reasoning of rewards and dangers of such action and negative earlier experiences (see Kleinhans and Bolt, 2013). Moreover, there are potentially important omitted variables. One of the factors in social disorganisation theory, ethnic heterogeneity, was not in the 
focus of this study, because relevant data was not available when this research was carried out. It is possible that the coefficient of Helsinki region to some extent reflects this, since estates in this region are likely to be more diverse in ethnic or cultural terms. However, further research is needed to investigate the impact and meaning of this diversity on the perceptions of social disorder in the Finnish context, characterised by a long history of cultural homogeneity and a relatively recent increase in non-European immigration. Also, the quality of the built environment may be a meaningful omitted variable, not available in our data. Hence, our results should not be read as exact causal effects. Another restriction of the study was that due to financial considerations the data were collected only from the Finnish-speaking residents, thus excluding the experiences of most immigrants. Finally, the register data on grids and survey data are from different years (2009 and 2013, respectively), but this is not likely to be a serious problem because grid characteristics typically change quite slowly in time.

We would like to conclude our study by outlining possible paths for future studies. An important question concerns the socio-economic trajectories of housing estates. Historical case descriptions alongside with statistical analyses of larger groups of housing estates could elucidate this matter in more detail and provide resources for making future predictions. Furthermore, our measures of normative regulation only partly explained the association of contextual disadvantage and perception of social disorder: what are the other mechanisms at play? Also the implications of neighbourhood disorder in the post-WWII estates of deindustrialising Nordic welfare states deserve more attention.

\section{Acknowledgements}

The authors are grateful to Linda Haapajärvi, Ansku Holstila, Lotta Junnilainen, Laura Kemppainen, Matti Kortteinen, Sebastian Kurtenbach, Henri Laukkanen, Outi Sirniö, discussants of the VTE seminar and three anonymous reviewers for valuable comments.

\section{Funding}

This work was supported by the Academy of Finland (project PREFARE, 2012-2015) and the Kone Foundation.

\section{References}

Andersson E, Naumanen P, Ruonavaara H \& Turner B (2007) Housing, socio-economic security and risks. A qualitative comparison of household attitudes in Finland and Sweden. European Journal of Housing Policy 7(2): 151-172.

Andersson R and Bråmå Å (2004) Selective migration in Swedish distressed neighbourhoods: can area-based urban policies counteract segregation processes? Housing Studies 19(4): 517-539.

Bellair P and Browning C (2010) Contemporary disorganization research: an assessment and further test of the systemic model of neighborhood crime. Journal of Research in Crime and Delinquency 47(4): 496-521.

Boyce I (2006) Neighbourliness and privacy on a low income estate. Sociological Research Online 11(3).

Brunton-Smith I and Sturgis P (2011) Do neighbourhoods generate fear of crime? An empirical test using the British Crime Survey. Criminology 49(2): 331-369. 
Ceccato V and Haining R (2005) Assessing the geography of vandalism: Evidence from a Swedish city. Urban Studies 42(9): 1637-1656.

Covington J and Taylor R (1991) Fear of crime in urban residential neighborhoods: implications of between- and withinneighborhood sources for current models. The Sociological Quarterly 32(2): 231-249.

Dekker K \& van Kempen R (2004) Large housing estates in Europe: current situation and developments. Tijdschrift voor Economische en Sociale Geografie 95(5): 570-577.

Dekker K and van Kempen R (2005) Large housing estates in Europe: a contemporary overview. In: van Kempen R, Dekker K, Hall S and Tosics I (eds) Restructuring Large Housing Estates in European Cities. Bristol: The Policy Press, pp. 19-47.

Friedrichs J and Blasius J (2003) Social norms in distressed neighbourhoods: testing the Wilson hypothesis. Housing Studies 18(6): 807-826.

Hankonen J (1994) Lähiöt ja tehokkuuden yhteiskunta: suunnittelujärjestelmän läpimurto suomalaisten asuntoalueiden rakentumisessa 1960-luvulla. Espoo: Otatieto.

Halpern D (2005) Social Capital. Cambridge: Polity.

Henning C and Lieberg M (1996) Strong ties or weak ties? Neighbourhood networks in a new perspective. Scandinavian Housing and Planning Research 13(1): 3-26.

Hipp J (2007) Block, tract, and levels of aggregation: neighborhood structure and crime and disorder as a case in point. American Sociological Review 72(5): 659-680.

Hirvonen Jukka, Kurlin A, Partanen E and Tikkanen P (2014) Näkökulmia ara-vuokra-asumiseen. Selvitys ara-vuokraasuntojen asukasrakenteesta ja asukasvalinnasta ara-asuntoihin.

Ympäristöministeriön raportteja 15/2014. Helsinki: Ympäristöministeriö.

Kearns A and Forrest R (2000) Social cohesion and multilevel urban governance. Urban Studies 37(5/6): 995-1017.

Kearns A and Mason P (2007) Mixed tenure communities and neighbourhood quality. Housing Studies 22(5): 661-691.

Kemppainen T, Lönnqvist $\mathrm{H}$ and Tuominen M (2014) Turvattomuus ei jakaudu tasan. Mitkä asuinalueen piirteet selittävät helsinkiläisten kokemaan turvattomuutta? Yhteiskuntapolitiikka 79(1): 5-20.

Kemppainen T and Saarsalmi P (2015) Perceived social disorder in suburban housing estates in the Helsinki region: a contextual analysis. Research on Finnish Society 8: 47-60.

Kim D (2008) Blues from the neighborhood? Neighborhood characteristics and depression. Epidemiological Reviews 30 : 101-117.

Kleinhans R and Bolt G (2014) More than just fear: on the intricate interplay between perceived neighborhood disorder, collective efficacy, and action. Journal of Urban Affairs 36(3): 420-446.

Kubrin C and Weitzer R (2003) New directions in social disorganization theory. Journal of Research in Crime and Delinquency 40(4): 374-402.

Kubrin C (2010) Shaw, Clifford R., and Henry D. McKay: Social Disorganization Theory. In: Wilcox P and Cullen FT (eds) Encyclopedia of Criminological Theory. Thousand Oaks: Sage, pp. 827-833.

Laaksonen S, Kemppainen T, Stjernberg M, Kortteinen M, Vaattovaara M and Lönnqvist H (2015) Tackling city-regional dynamics in a survey using grid sampling. Survey Research Methods 9(1): 45-55.

Murie A, Knorr-Siedow T, van Kempen R (2003) Large Housing Estates in Europe. General Developments and Theoretical Backgrounds. RESTATE report 1. Utrecht: Urban and Regional research centre. 
Musterd S and van Kempen R (2007) Trapped or on the springboard? Housing careers in large housing estates in European cities. Journal of Urban Affairs 29(3): 311-329.

Paugam S (2011) La disqualification sociale. 4th edition. Paris: PUF.

Paugam S, Roullin B and Wlodarzik M (2009) La constitution des liens sociaux dans les cités socialement disqualifiées. Paris: I'Union sociale pour l'habitat.

Power A (1997) Estates on the Edge. Basingstoke: Macmillan.

Ristimäki M, Tiitu M, Helminen V, Söderström P, Oinonen K and Kalenoja H (2013) Yhdyskuntarakenteen vyöhykkeet Suomessa. Jalankulku-, joukkoliikenne- ja autovyöhykkeiden kehitys vuosina 1985-2010. Helsinki: Suomen ympäristökeskus.

Ross C \& Mirowsky J (1999) Disorder and decay. The concept and measurement of perceived neighborhood disorder. Urban Affairs Review 34(3): 412-432.

Ruonavaara H (1987) The Kemeny approach and the case of Finland. Scandinavian Housing and Planning Research 4(3): 163-177.

Ruonavaara H (1996) The home ideology and housing discourse in Finland 1900-1950. Housing Studies 11(1): 89-104.

Sampson R and Groves W (1989) Community structure and crime: testing social-disorganization theory. American Journal of Sociology 94(4): 774-802.

Sampson R, Raudenbush S and Earls F (1997) Neighborhoods and violent crime: a multilevel study of collective efficacy. Science 277(5328): 918-924.

Sampson R and Raudenbush S (1999) Systematic social observation of public spaces: a new look at disorder in urban neighborhoods. American Journal of Sociology 105(3): 603-651.

Sampson R (2009) Disparity and diversity in the contemporary city: social (dis)order revisited. The British Journal of Sociology 60(1): 1-31.

Sautkina E, Bond L and Kearns A (2012) Mixed evidence on mixed tenure effects: findings from a systematic review of UK studies, 1995-2009. Housing Studies 27(6): 748-782.

Shaw C and McKay H (1942) Juvenile Delinquency and Urban Areas. Chicago: The University of Chicago Press.

Skifter Andersen H (2003) Urban Sores. On the Interaction Between Segregation, Urban decay and Deprived Neighbourhoods. Aldershot: Ashgate.

Skifter Andersen H (2008) Why do residents want to leave deprived neighbourhoods? The importance of residents' subjective evaluations of their neighbourhood and its reputation. Journal of Housing and the Built Environment 23: 79101.

Statistics Finland (2013) Liitetaulukko 3. Asuntokunnat ja henkilöt asunnon hallintaperusteen mukaan 1970-2012. Available at: http://www.stat.fi/til/asas/2012/01/asas_2012_01_2013-10-18_tau_003_fi.html (accessed 19.9.2016). [Tenure statistics]

Statistics Finland (2014) Grid Database. Available at: http://www.stat.fi/tup/ruututietokanta/index_en.html (accessed 11 January 2014).

Steptoe A and Feldman P (2001) Neighborhood problems as sources of chronic stress: development of a measure of neighborhood problem, and associations with socioeconomic status and health. Annals of Behavioral Medicine 23(3): 177185

Stjernberg M (2015) Suomalaisten 1960-ja 1970-lukujen lähiöiden sosioekonominen kehitys ja alueellinen eriytyminen. Yhteiskuntapolitiikka 80(6): 547-561. 
Sutherland A, Brunton-Smith I and Jackson J (2013) Collective efficacy, deprivation and violence in London. British Journal of Criminology 53: 1050-1074.

Thorlindsson T and Bernburg J (2004) Durkheim's theory of social order and deviance: a multi-level test. European Sociological Review 20(4): 271-285.

Tunstall R and Coulter A (2006) Twenty-five Years on Twenty Estates. Turning the Tide? Bristol: The Policy Press.

Wassenberg F (2013) Large Housing Estates: Ideas, Rise, Fall and Recovery: the Bijlmermeer and Beyond. Amsterdam: IOS.

Varady D and Schulman H (2007) Social disorders in the early stages of public housing decline: a Helsinki case study. Housing Studies 22(3): 313-332. 